\title{
New model of Oral Mucositis with 5-Fluorouracil chemo-induced in Wistar rats without the use of anesthesics
}

\author{
Novo modelo de Mucosite Oral quimioinduzida \\ com 5-Fluorouracil em ratos Wistar \\ sem uso de anestésicos
}

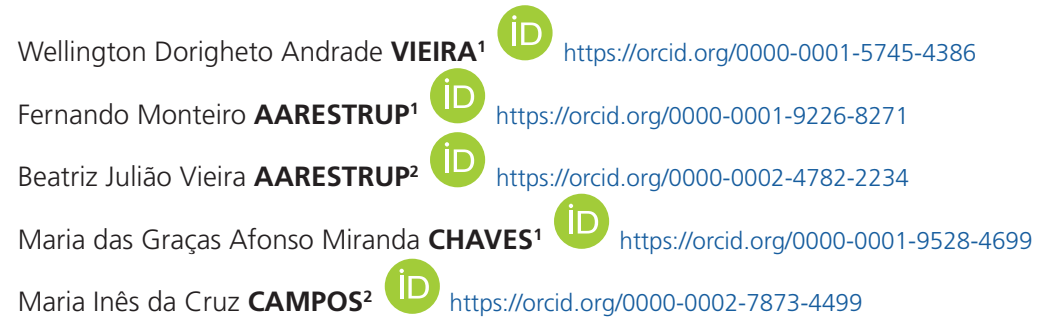

\section{ABSTRACT}

Introduction: Oral mucositis $(\mathrm{OM})$ is considered the most frequent acute side effect of the antineoplasic treatment, with ulcerative lesions resulting from a painful symptomatology, affecting the oral cavity in response to the Antineoplastic treatment. In order to study these side effects, experiments in animal models are necessary, using antineoplastic drugs for the induction of OM and anesthetics, mainly Ketamine and Xylazine, to perform scarification of the cheeks. Objective: The goal is to report an experimental model of induced OM, without the use of anesthetics for the scarification stage of the animal cheeks. Methods: Fourty five male Wistar rats, 7 weeks old and weighting 220g, were used, divided into 2 groups; with OM induced by 5-Fluorouracil intraperitoneal administration. Two days later, Group I was physically contained, in contrast, Group II were anesthetized with Ketamine and Xylazine, focusing on irritating the cheek mucosa using the tip of a sterile needle, in order to potentialize the development of OM. The animals were euthanized with an anesthetic overdose. Results: Concerning the experiment of 5-Fluorouracil chemo-induced of OM, where the irritation was performed by physical containment, without the use of anesthetics (Ketamine and Xylazine), the animals had a longer survivability and a rapid improvement of the side effects induced by chemotherapy. Conclusion: This new model is promising, considering that the use of anesthetics (Ketamine and Xylazine) showed a high mortality rate. In the absence of anesthesia, all the animals survived until the end of the experiment involving chemotherapy model with 5-Fluorouracil and physical restraint.

Indexing terms: Animal models. Ketamine. Stomatitis. Xylazine.

$\boldsymbol{\nabla} \boldsymbol{\nabla} \nabla \boldsymbol{v}$

1 Universidade Federal de Juiz de Fora, Faculdade de Odontologia, Departamento de Clínica Odontológica. Juiz de Fora, MG, Brasil.

2 Universidade Federal de Juiz de Fora, Instituto de Ciências Biológicas. Rua Lindalva de Paula Ribeiro, 240, Bosque Imperial, 36036-466, Juiz de Fora, MG, Brasil. Correspondence to: MIC CAMPOS. E-mail: <clinin@terra.com.br>.

$\boldsymbol{\nabla} \boldsymbol{\nabla} \boldsymbol{\nabla}$

How to cite this article

Vieira WDA, Aarestrup FM, Aarestrup BJV, Chaves MGAM, Campos MIC. New model of Oral Mucositis with 5-Fluorouracil chemoinduced in Wistar rats without the use of anesthesics. RGO, Rev Gaúch Odontol. 2021;69:e20210045. http://dx.doi.org/10.1590/1981863720210004520200012 


\section{RESUMO}

Introdução: A mucosite oral (MO) é considerada o efeito colateral agudo mais frequente do tratamento antineoplásico, com lesões ulcerativas decorrentes de sintomatologia dolorosa, acometendo a cavidade oral em resposta ao tratamento antineoplásico. Para estudar esses efeitos colaterais, são necessários experimentos em modelos animais, utilizando fármacos antineoplásicas para a indução de $\mathrm{MO}$ e anestésicos, principalmente Cetamina e Xilazina, para realizar a escarificação das bochechas. Objetivo: Relatar um novo modelo experimental de MO induzida, sem o uso de anestésicos, para a etapa de escarificação das bochechas dos animais. Métodos: Foram utilizados 45 ratos Wistar machos, com 7 semanas de idade e peso de 220g, divididos em 2 grupos com Mo induzida pela administração intraperitoneal de 5-fluorouracil. Dois dias depois, o Grupo I foi contido fisicamente, ao contrário, o Grupo II foi anestesiado com Cetamina e Xilazina, com foco em irritar a mucosa da bochecha com a ponta de uma agulha estéril, a fim de potencializar o desenvolvimento de MO. Os animais foram eutanasiados com sobredose de anestésica. Resultados: Em relação ao experimento de 5-Fluorouracil quimioinduzido para MO, onde a irritação foi realizada por contenção física, sem o uso de anestésicos (Cetamina e Xilazina), os animais tiveram maior sobrevida e rápida melhora dos efeitos colaterais induzidos por quimioterapia. Conclusão: Este novo modelo é promissor, visto que o uso de anestésicos (Cetamina e Xilazina) apresentou elevada mortalidade. Porém, na ausência de anestesia, todos os animais sobreviveram até o final do experimento envolvendo este modelo de quimioterapia induzida com 5-fluorouracil e contenção física.

Termos de indexação: Modelos animais. Katamina. Estomatite. Xilazina.

\section{INTRODUCTION}

According to Lamounier [1], the first law established in Brazil for didactic and scientific animal practices was created on May 8, 1979 - Law 6.638/1979 and Law 11.794/2008 was subsequently published and regulated on June 15, 2009, and it is used until today.

In Brazil, the CEUA - Committee for Ethics in Animal Use - aims to evaluate the decisions involving experimental animals, Analyzing the defensive aspects, looking after scientific research in the animal field and guiding researchers on existing protocols, so that studies meet their needs without violating animal rights [2].

In order to reduce the transmission of peripheral pain impulses to the central nervous system, it is possible to use general anesthesia, but it cannot totally inhibit them [3].

For Fatoni [4], numerous studies are carried out on experimental animals, the laboratory mouse being one of the animal most commonly used for scientific research.

According to the authors Gehrcke, Trein and Massone (2007), in order to achieve the ideal immobility of the animals during the procedures, general anesthesia should be used, leading to a total loss of consciousness. General anesthesia is divided into surgical anesthesia, which is the set of immobilization, loss of consciousness, insensitivity, muscle relaxation and analgesia; and dissociative anesthesia, which is composed of catalepsy, analgesia and altered consciousness [5].

According to the same authors, although there are more modern protocols, the most used anesthetics in laboratory animals are Ketamine and Xylazine. Presently, it is not possible to perform surgical procedures without the presence of opioid analgesics [5].

Xylazine ( $a$-2-adrenergic agonist) is a potent sedative capable of producing moderate analgesia, potentiating most anesthetics, leading to cardiovascular and respiratory depression. It use causes cardiac arrhythmias, hyperglycemia and diuresis $[6,7]$. Ketamine has severe limitations in most animal species, requiring it use in combination with Xylazine. This drug causes immobility of animals, moderate respiratory depression, increased blood pressure and skeletal muscle tone, producing a state of sedation with apparent lack of awareness, depressing of the corneal blink reflex and maintaining laryngeal and pharyngeal reflexes. In rodents, their effects are variable and high rates of total immobilization may be required. However, Ketamine may be neurotoxic. Studies have shown that neurons in the cerebral cortex of rats become morphologically damaged after the application of phencyclidine or Ketamine, although this could be avoided by the administration of anticholinergics, diazepam or barbiturates $[8,9]$.

Since 1990, Sonis and his colleagues have been studying Oral Mucositis (OM) in an animal model, using Mice. Due to the increase in the number of the disease cases as a consequence of chemotherapy and radiotherapy treatments in recent years, the study of mucositis has been increasing in the same way. Oral mucositis is the term used to describe these alterations, being considered a syndrome characterized by erythema and ulceration at an oral cavity, which may result in pain and dysphagia, compromising the nutrition and oral hygiene of patients [10]. 
For the treatment of neoplasias, the two main drugs of choice are 5-Fluourouracil (5-FU) and Methotrexate (MTX); both of which have proven antitumor action and are considered safe drugs. The 5-FU is the drug of choice for antineoplastic treatment because of its low cost and better effectiveness in antineoplastic treatment compared to other drugs; unlike MTX which already has a high financial cost. Both have effective antimitotic activity, acting on malignant tumor cells, as well as on normal cells, promoting unstable mitotic activity in glandular tissues, epithelial and lining cells, and also in hematopoietic cells with origin in the bone marrow $[10,11]$.

Chemotherapy is the standard treatment for cancer and is directly associated with patient survival [8]. Consequently, experimental cancer research has allowed the establishment of more effective therapeutic protocols, as well as the modulation of biological reactions and their effects on better clinical outcomes, combined with fewer side effects [12-14].

Piglet et al. [15] and Lima et al. [16], in their modified chemo-induced experimental mucositis model, used 5-FU, general anesthesia and irritation of the cheeks. The animals presented potentiated side effects, a pattern of hyperemia, hemorrhage, extensive ulcers and abscesses. On the animals that received only anesthesia and bilateral scarification of the cheeks, the lesions were much more significant.

Medeiros et al. [13] induced OM in male adult golden Hamsters through two intraperitoneal 5-FU applications and bilateral cheek scarification after general anesthesia. The authors reported that the group which did not realized chemotherapy, and that was anesthetized, presented a $100 \%$ survival rate. The groups medicated with 5-FU and anesthetized presented a mortality of $60 \%$. Campos et al. [12], in its experimental model of chemotherapy induced by 5-FU and anesthesia (Ketamine and Xylazine) for scarification of the cheeks, described that nine animals died, while others presented ocular, nasal and anal bleeding, weight loss, extensive ulcerated areas and erythematous.

Despite the high prevalence and the years of extensive study into nature of $\mathrm{OM}$, very few treatment options exist, taking in consideration that the efficacy and utility of those available is limited, therefore, preventing symptoms of $\mathrm{OM}$, or treating it quickly, brings an improvement of a patient quality of life, reducing the need for treatment interruption. At the moment, various treatments are used, but they do not seem to be adequate, and also have little preventive effect. The use of animals is very important regarding the development, physiopathology and elucidation of the mechanisms in action related to the new drugs against $\mathrm{OM}$, and, as a side effect of anticancer drug therapy, to be possible "in vivo" [11-14].

In addition, any new potential antimucotoxic agent must be first subjected to rigorous testing in animal models to prove efficacy and safety before transitioning to early clinical trials. Animal models of mucositis have provided extensive information relating to mechanisms of cancer therapy-induced mucosal injury [15]. We had an increase in the variety and complexity of models over time, from basic survival end points to specialized biomarkers of damage. In line with this, a number of models have become routinely utilized for testing of new antimucotoxic agents. Many factors cause difficulties in animal research, the principal being the need to anesthetize animals on a regular basis. With the constant application of drug screening and agent testing for potential cancer treatments, and supportive agents to use in the clinic, the animal model of mucositis will continue to be a highly valuable tool [16].

Based on the above, this study aims to present a new model of OM with 5-Fluorouracil chemoinduced in Wistar rats without use of anesthesia.

\section{METHODS}

A total of 45 male Wistar rats were used, within the age of 7 weeks and body weight of $220 \mathrm{~g}$. The entire experiment was performed at the Laboratory of Immunopathology and Experimental Pathology, more specifically the Center of Reproductive Biology, Federal University of Juiz de Fora (MG, Brazil) and was approved by the Animal Research Committee (notion $n^{\circ}$ 005/2018). The animals were kept in pairs, inside cages quilted with shavings, at room temperature and controlled lighting, with ad libitum access to water and food. Surgical procedures and animal treatments were conducted in accordance with the Guidelines for Institutional Animal Care.

The 45 animals used for induction of $\mathrm{OM}$ in an experimental chemotherapy model were divided into 2 groups. Group I: 36 animals with chemo-induced oral mucositis, without the use of anesthetic, using only with physical restraint (figure 2C); Group II: 9 animals with chemo- 
induced oral mucositis, under anesthesia with Ketamine and Xylazine (figure 2D), and their reflexes were evaluated by means of angular compression of the two posteriors legs. Oral mucositis was induced in all groups by two intraperitoneal (i.p.) administrations of 5-FU - day 16 and $18-(60$ and $40 \mathrm{mg} / \mathrm{kg}$, respectively). For the induction of oral mucositis, the chemotherapeutic 5-Fluorouracil was used, according to an experimental oral mucositis model previously described by Campos et al. (2015). On days 19 and 20 the animals had their cheek mucosa irritated by scarification. The animals of Group I were submitted to this described procedure without anesthetic, and the animals of Group II were submitted to the same mucosal scarification under anesthetic substance (Ketamine and Xylazine). This was performed by dragging the tip of an 18-gauge needle, twice, in a linear manner, across the everted cheeks. The scarification is part of induction of $\mathrm{OM}$, because the rodents do not have posterior teeth that touch the oral mucosa, such as the humans, and it's necessary to mimic this act in order to potentialize the development of OM. On days 24, 27 and 30, after the initial injection of 5-FU, the animals were euthanized with anesthetic overdose. In each day 15 animals were euthanized (Group I $-n=12$, Group II $-n=3$ ), because on this day is possible to see the evolution, the start of the healing process, and the final cure of OM (figure 1).

The entire research was performed by 2 operators, one for physical restraint, other for the application of drugs and scarification.

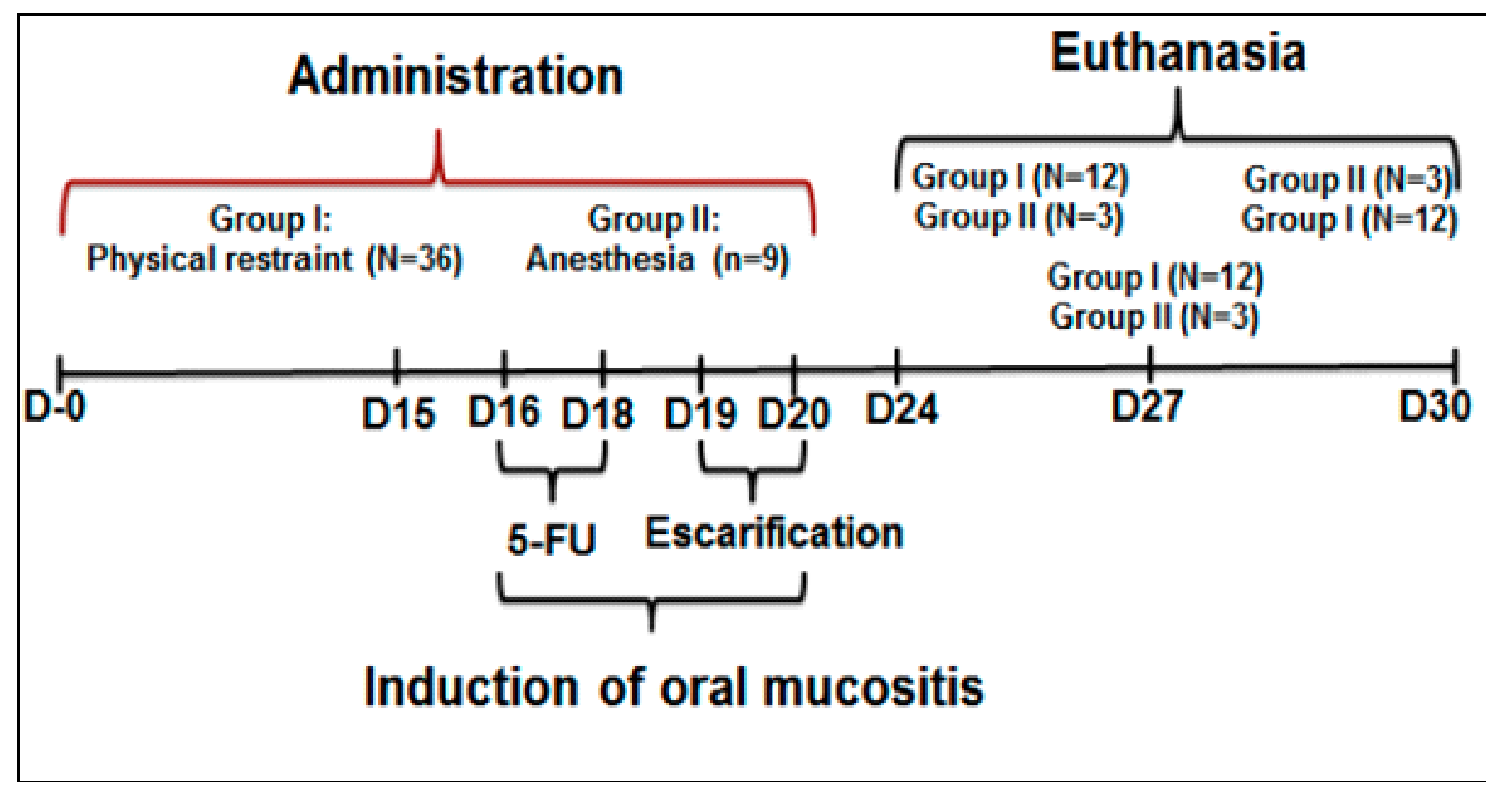

Figure 1. Table of drug administration, induction of oral mucositis, scarification and euthanasia.

Note: D0 - D15: Handling of the animals without the intervention of any medicine (Group I and Group II); D16/D18: First/Second application of 5-FU Chemo (Group I and Group II); D19/D20: First/Second scarification of the cheek mucosa related to the animals in Group I under physical containment / scarification of the cheek mucosa related to the animals in Group II under general anesthetics; D24/D27/D30: Euthanasia of 15 animals (Group I: $n=12$ and Group II: n=3, consecutively)

\section{RESULTS}

After the application of the 5-FU chemotherapy, the animals of Group I, (who did not receive anesthesics - Ketamine and Xylazine), only physical restraint, had a longer survivability and a rapid improvement. The main side effects observed clinically, were: slimming, decreased food intake (figure 2A), diarrhea and discreet bleeding around the eyes, extending until the second dose on day 18. It is noteworthy that, immediately after the end of the induction of OM by $5-\mathrm{FU}$, immediate improvement of the clinical condition was seen through scarification, observed 
by a decrease in diarrhea, reduction of ocular bleeding, weight gain and, consequently, improvement of dietary intake. There was no animal death, and they remained stable until the end of the experiment - days 24,27 and 30 (figure 2B).

Group II animals, who received anesthesia (Ketamine and Xylazine) for scarification, presented slimming (visually noticeable), extensive nasal bleeding, and ocular and nasal secretions were observed at the second day of the induction of oral mucositis with $5-\mathrm{FU}(60 \mathrm{mg} / \mathrm{kg}$ and $40 \mathrm{mg} / \mathrm{kg}$ ), for scarification of the cheek mucosa (Day 18). In this group, 5 animals died during the research, and 4 had to be euthanized in advance to avoid their death.

The four animals remaining in group 2 had has difficulty to return from anesthesia, and also difficulty in locomotion. During the clinical observation, 2 of them stopped ingesting rations, and, beyond that, had extensive ocular, nasal, anal bleeding, with considerable slimming, prostration, ocular and nasal secretion (figure 2B).

\section{DISCUSSION}

Oral mucositis (OM) is a side effect of antineoplastic treatment in patients undergoing chemotherapy and radiotherapy. It is a common, symptomatic and limiting condition of the regime related to head and neck radiotherapy. The clinical appearance of OM varies from mucosal redness to symptomatic ulcers. Histological OM results in a thin epithelium and ulcers that are caused by the scaling of the basal epithelium, on the epithelial cell layer, followed by inflammation, with subsequent bacterial infection $[15,16]$.

Studies suggest that chemotherapy acts on the basal layer of the cellular epithelium, inducing a loss of

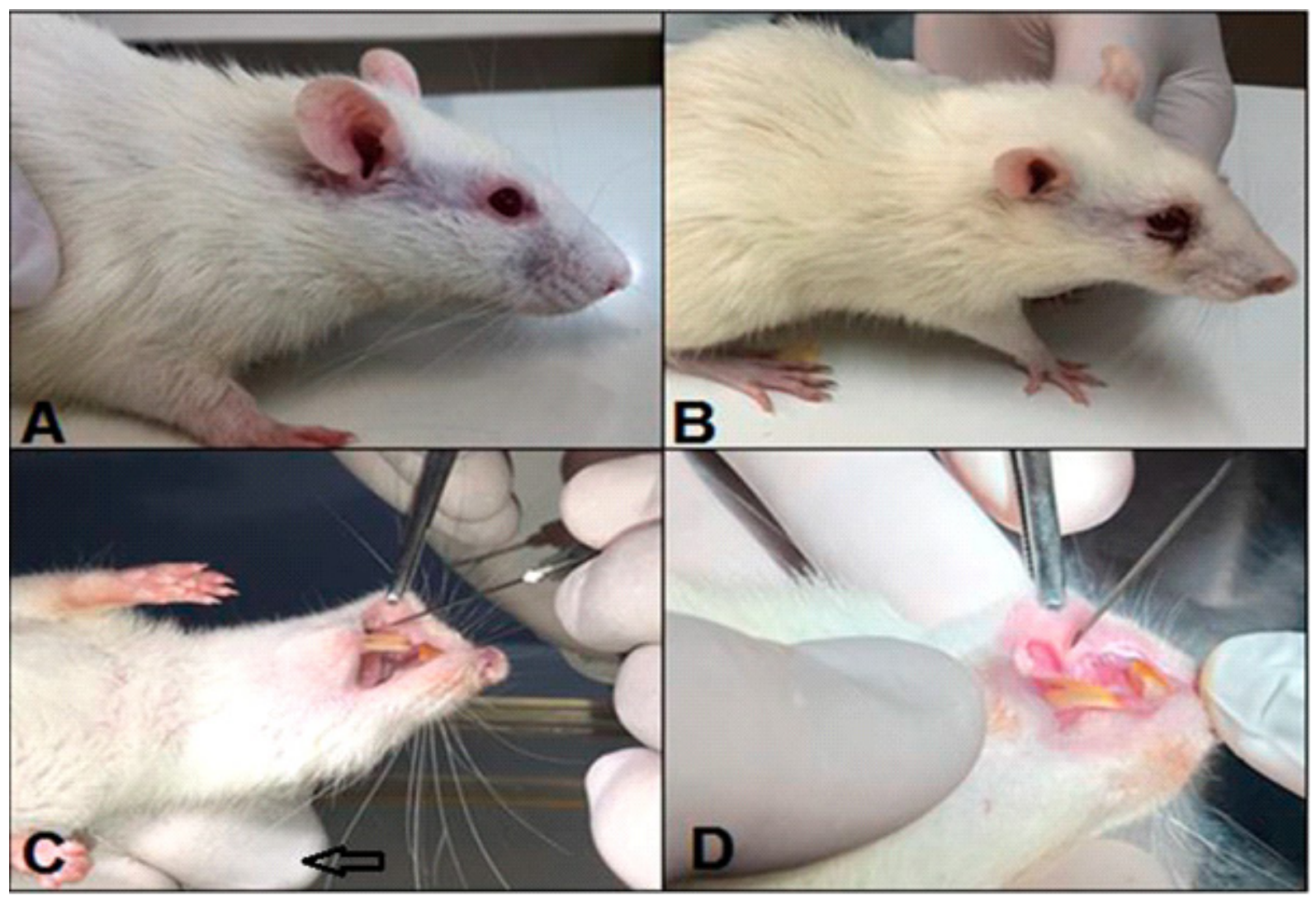

Figure 2. Photograph - A: Group I - showing the clinical state of the animal after 15 days of the experiment, without the use of anesthesia for scarification of the cheeks for induction of oral mucositis; B: Group II - ocular and nasal bleeding in Wistar rat after chemotherapy induced with 5-fluorouracil, anesthesia and scarification. C: Group I - being contained manually and the cheek mucosa being scarified; D: Group II - Realization of a bilateral scarification of the cheeks at the day 19 and 20, with an animal under general anesthesia (ketamine and xylazine), after the application of the chemotherapy 5-Fluorouracil at day 18 and 19 . 
the self-renewing capacity of the same, preventing DNA replication $[12,13,16,17]$.

Clinically, in this experiment, it can be observed that, in a number of 45 animals, there was a significant survival rate, and with the death of only 5 animals (Group II). Despite the absence of anesthesia to perform the scarification of the cheeks (Group I), the animals were physically contained to perform the research. In their study, Medeiros et al. [13] reported a mortality rate of $60 \%$ of the animals that underwent induced chemotherapy and anesthesia (Ketamine and Xylazine) for scarification. It can be seen that anesthesia further enhances the side effects of antineoplastic treatment [13].

We observed in Group I, a rapid improvement in cachexia, nasal and eye bleeding, re-establishment of food intake and, consequently, the improvement of body weigh was also observed. In corroboration with Lima et al. [16], Medeiros et al. [13] and Campos et al. [12], the animals presented, after induction of OM, the weight loss, decreased food intake and an onset of diarrhea, extending to the second dose when the animals began to show slight ocular bleeding and prostration after induction of chemotherapy.

Numerous experimental models of induced mucositis have been developed in order to investigate the mechanisms related to the development of this disease and to evaluate the effects of different therapeutic agents. They used Ketamine and Xylazine to perform mucosal scarification, but with a large number of animal's death [11,16-20].

Decreased respiratory was observed in the animals of Group II. It can be explained by methadone, which, when binding to $\mu$ receptors, causes and activates respiratory rhythm depression [18-19]. The decrease body temperature observed in Group II may be related to the depressant effect of ketamine on thermoregulatory mechanisms, in addition to the fact that small rodents easily lose heat when anesthetized [21-23].

\section{CONCLUSION}

When using anesthesia (Ketamine and Xylazine) in an experimental chemotherapy model with 5-FU associated, the side effects are potentiated and contribute to the mortality of the animals, Due to the fact that anesthesia (Ketamine and Xylazine) was not used, there was a higher survivability rate of the animals, and they were euthanized at the planned end of the experiment.

\section{Acknowledgments}

The authors would like to thank the teachers: Vera Maria Peters and Akinori Cardozo Nagato; the Graduate Program in Health and Dentistry; Federal University of Juiz de For a - UFJF; Center of Reproduction Biology - CBR; agencies promoting animal research: Rede Mineira de Bioterismo / FAPEMIG 31/11, TOXIFAR 26/11 and CNPq.

\section{Collaborators}

WDA Vieira, conceptualization (equal), formal analysis (equal), investigation (equal), methodology (supporting), supervision (equal), visualization (lead) And writing-original draft (supporting). BKV AARESTRUP, methodology (supporting), supervision (supporting) and writing-review \& editing (supporting). FM AARESTRUP, methodology (supporting), validation (supporting) and writing-review \& editing (supporting). MIC Campos, conceptualization (lead), formal analysis (lead), investigation (equal), methodology (supporting) and writingreview \& editing (equal).

\section{REFERENCES}

1. Lamounier CGB (2015) The process of construction of the law. [s.I.]: [s.n.]; 2015.

2. Feijó AGS. The role of institutional ethics committees in the use of animals in scientific research and teaching. Rev Bioethics. 2006;12:11-22. http://dx.doi.org/10.1590/198380422017253220

3. Katz J. Pre emptive analgesia: importance of timing. Can J Anesthe. 2006;48:105-14. http://dx.doi.org/10.1007/BF03019721

4. Fatoni DT. Anesthesia in research animals. In: Manina J. Anesthesiology: principles and techniques. Porto Alegre: Artmed; 2004.

5. Gehrcke MI, Trein TA, Massone F. Association ketamine and xylazine: the great pharmacological ignorance. Apamvet. 2017;8:18-20. http://dx.doi.org/10.1590/S010286502012000200008

6 Green CJ, Knight S, Precious S, Simpkin S. Ketamine alone and combined with diazepam or xylazine in laboratory animals: a 10-year experience. Lab animals. 1980;15(2):163-70. http://dx.doi.org/10.1258/002367781780959107

7. Greene SA, Thumon JC. Xylazine: a review of its pharmacology and use in veterinary medicine. J Vet Pharmacol Therapeutics. 1988;11:295-313. http://dx.doi. org/10.1111/j.1365-2885.1988.tb00189.x 
8. White PF, Way WL, Trevor AJ. Ketamine: its pharmacology and therapeutic uses. Anestesiol. 56:119-36. http://dx.doi. org/10.1097/00000542-198202000-00007

9. Sonis ST, Tracey C, Shklar G, Jenson J, Florine D. An animal model for mucositis induced by cancer chemotherapy. Oral Surg Oral Med Oral Pathol. 1990;69:437-443. http://dx.doi. org/ 10.1016/0030-4220(90)90376-4

10. Walladbegi J, Smith SA, Grayson AK, Murdoch C, Jontell M, Colley HE. Cooling of the oral mucosa to prevent adverse effects of chemotherapeutic agents: An in citro study. J Oral Pathol Med. 2018;1-7. http:dx.doi.org/10.1111/jop.12696

11. Ahmed AAM, Selim MAA, El-Sayed NM. a-Lipoic acid ameliorates oral mucositis and oxidative stress induced by methotrexate in rats. Histological and immunohistochemical study. Life Sci. 2018;15:51-59. http:dx.doi.org/10.1016/j. Ifs.2017.01.001

12. Campos MIC, Vieira WDA, Campos CN, Aarestrup BJV, Aarestrup FM. Atorvastatin and trans-caryophyllene for the prevention of leukopenia in an experimental chemotherapy model in Wistar rats. Mol Clin Oncol. 2015; 3(4):825-28. http:dx.doi.org/10.3892/mco.2015.544

13. Medeiros CACX, Leitão RFC, Macedo RN. Effect of atorvastatin on 5-fluorouracil experimental oral mucosits. Cancer Chemother Pharmacol. 2011;67:1085-1100. http:dx. doi.org/ 10.1007/s00280-010-1409-7

14. Kirk J, Shah N, Noll B, Stevens CB, Lawler M, Mougeot FB, et al. Text mining-based in silico drug discovery in oral mucositis caused by high-dose cancer therapy. Support Care Cancer. 2018;8:2695-705. http:dx.doi.org/10.1007/s00520-018-4096-2

15. Piglet RFC, Ribeiro RA, Bellaguarda EAL, Macedo FDB, Silva $L R$, Oriá $R B$, et al. Role of nitric oxide on pathogenesis of 5-Fluorouracil induced oral mucositis in hamster. Cancer Chemother Pharmacol. 2007; 59:603-612. http:dx.doi. org/10.1007/s00280-006-0301-y
16. Lima V, Brito GAC, Cunha FQ, Rebouças CG, Falcon BAA, Augusto RF, et al. Effects of the tumor necrosis factor-alpha inhibitorspentoxifyllineand thalidomideinshort-termexperimental oral mucositis in hamsters. Eur J Oral Sci. 2005;113:210-217. http:dx.doi.org/10.1111/j.1600-0722.2005.00216.x

17. Bowen JM, Gibson RJ, Keefe DM. Animal models of mucositis: implications for therapy. J Support Oncol. 2011; 9(5):161-8. http:dx.doi.org/10.1016/j.suponc.2011.04.009

18. Campos MIC, Campos CN, Aarestrup FM, Aarestrup BJV. Oral mucositis in cancer treatment: natural history, prevention and treatment. Mol Clin Oncol. 2015; 337-340. http://dx.doi. org/10.3892/mco.2014.253

19. Cinausero M, Aprile G, Ermacora P. New frontiers in the pathobiology and treatment of cancer regimen-related mucosal injury. Injury Front Pharmacol. 2017; 8:354. http:// dx.doi.org/10.3389/fphar.2017.00354

20. Viera WDA, Nagato AC, Campos MIC. Experimental model of oral and intestinal mucositis in wistar rats. Rev Int Exp. 2018. http://dx.doi.org/10.34019/2177-3459.2018.v10.27458

21. Wamsley JK. Muscarinic cholinergic receptors undergo axonal transport in the brain. Eur J Pharmacol. 1981;86:309-10. http://dx.doi.org/10.1016/0006-8993(81)90193-1

22. Wixson SK; White WJ; Hughes HC, Marshall WK, Lang CM. The effects of pentobarbital, pentobartial, fentanyldroperidol, ketamine-xylazine and ketamine-diazepam on noxious stimulus perception in adult male rats. Lab Anim Sci. 1987; 37:731-35.

23. Rodrigues SF; Oliveira MA; Martins OJ, Martins JO, Sannomiya P, Cássia TR, et al. Differential effects of chloral hydrate-and ketamine/xylazine-induced anesthesia by the s.c. route. Life Sci. 2009;79:1630-37. http://dx.doi.org/10.1016/j.Ifs.2006.05.019

Received on: 19/2/2020 Final version resubmitted on: 3/4/2020 Approved on: 27/4/2020 